\title{
A study of hematological parameters in patients with COVID-19 infection at a tertiary care centre
}

\author{
Keval Arvindbhai Patel ${ }^{1}$, Riddhi A Parmar ${ }^{1}$, Bhawana S Sharma ${ }^{1}$, Mansi \\ Thacker ${ }^{1}$, Navin Patel ${ }^{1}$, Bimal Patel ${ }^{1}$ \\ ${ }^{1}$ Department of Pathology, Gujarat Adani Institute of Medical Sciences, Bhuj, Kachchh, Gujarat, India
}

\section{Keywords: \\ Coronavirus; Lymphocytes; Lymphopenia; Thrombocytopenia;}

\begin{abstract}
Background: The corona virus disease 2019 is caused by the virus SARS-CoV-2 and is declared as a global pandemic by World Health Organization. Alterations in various hematological parameters have been recently documented in the world literature in SARS-Cov-2 infection. However, still there is paucity of hematological data in these patients. Hence this study is an attempt to evaluate the pattern of the hematological parameters in COVID-19 patients in the Indian population in our region. The objective of the study is to see the pattern of alteration in hematological parameters with emphasis on total leukocyte count, absolute lymphocyte count and platelet count in COVID 19 positive patients.
\end{abstract}

Materials and Methods: This is an observational study in 50 patients with laboratory-confirmed COVID-19 status admitted to G.K. General Hospital \& Gujarat Adani Institute of Medical Sciences, Bhuj, from 1st April 2020 to 30th June 2020. Statistical analysis of the data was carried out, and relevant findings were presented.

Results: Among the 50 patients, there were $35(70 \%)$ males and $15(30 \%)$ females with an age range from 6 months to 82 years with twenty-five patients above 50 years. There was lymphopenia in 18 patients $(36 \%)$, leukopenia in 2 patients (4\%) and thrombocytopenia in $8(16 \%)$ patients.

Conclusions: Majority of the patients were elderly, and there was a male predominance. There was moderate to severe lymphopenia and mild thrombocytopenia.

\section{Correspondence:}

Dr. Bimal Patel, $M D$

Associate Professor, Department of Pathology,

Gujarat Adani Institute of Medical Sciences, Bhuj, Kachchh, Gujarat, India ORCID ID: 0000-0003-4453-3303

Email: bimaldoctor@gmail.com

Received : September $22^{\text {nd }} 2020$; Accepted : January $19^{\text {th }} 2021$

Citation: Patel KV, Parmar AR, Sharma BS, Thacker M, Patel N, Patel B. A study of hematological parameters in patients with COVID-19 infection at a tertiary care centre. J Pathol Nep 2021;11:18528.DOI: $10.3126 /$ jpn.v11i1.31401

Copyright: This is an open-access article distributed under the terms of the Creative Common. Attribution 4.0 International License, which permits unrestricted use, distribution, and reproduction in any medium, provided the original author and source are credited.

\section{INTRODUCTION}

China on December 31, 2019, reported on a cluster of cases suffering from severe pneumonia of unknown cause in Wuhan, Hubei province. ${ }^{1}$ Two week later new virus variant called Severe acute respiratory coronavirus syndrome 2 (SARS-CoV-2) caused by coronavirus disease 2019 (COVID-19) was found in an outbreak in Wuhan, China, and spread to the rest of the world. More than one million people worldwide are affected by this pandemic. The first case of COVID-19 in India was reported on 30 January 2020 in Kerala. 
Six coronaviruses are known to infect humans prior to detection of SARS-CoV-2. SARS-CoV2 belongs to the beta coronavirus family. Four of these coronaviruses cause seasonal, predominantly mild respiratory disease and have a high prevalence worldwide, accounting for 15-30 percent of upper respiratory tract infections. ${ }^{2}$ The other two coronaviruses have led to major epidemics with deaths mainly from respiratory disease; Severe acute respiratory syndrome (SARS) was in 2002-03 by SARS-CoV, and in 2012 by the Middle East respiratory syndrome (MERS$\mathrm{CoV}$ ) in the Middle East. ${ }^{3,4}$

SARS-CoV2 is a single-strand positive RNA virus with a large genome $(30 \mathrm{~kb})$. The virus has club-shaped spikes that are visible as a solar corona under the electron microscope; hence the name-coronavirus. It attaches to the angiotensinconverting enzyme 2 receptors (ACE2) ${ }^{5}$ via the spike protein and enters into the host cell. ACE2 receptors are located in the lungs, nasopharynx, heart, kidneys, liver, intestines, vascular endothelium, testicles, and also in cortex, especially in cardiovascular regulatory areas of the brain stem. ${ }^{6,7}$ Several studies showed lymphopenia, a cardinal laboratory finding, among COVID-19 patients ${ }^{8}$ in different areas, including studies performed in China 9-13,16,17,20-22, Singapore ${ }^{14,15}$ and the USA. ${ }^{18,19}$ Severe COVID-19 can lead to critical illness, with acute respiratory distress (ARDS) and multi-organ failure (MOF) as its primary complications, eventually followed by intravascular coagulopathy. ${ }^{23}$ Although more in-depth research on the underlying etiology is necessary, several factors may contribute to COVID-19 associated lymphopenia. It has been shown that lymphocytes express the ACE2 receptor on their surface, ${ }^{24}$ thus SARS-CoV-2 may directly infect those cells and ultimately lead to their lysis. Furthermore, the cytokine storm is characterized by markedly increased levels of interleukins (mostly IL-6, IL-2, IL-7, granulocyte colonystimulating factor, interferon- $\gamma$ inducible protein 10, MCP1, MIP1-a), and tumor necrosis factor-alpha (TNF-alpha), which may promote lymphocyte apoptosis. ${ }^{25-27}$ Substantial cytokine activation may be associated with atrophy of lymphoid organs, including the spleen, and further impairs lymphocyte turnover. ${ }^{28}$ Coexisting lactic acidosis, which may be more common among cancer patients who are at higher risk for complications from COVID- $19,{ }^{29}$ can also hinder the dissemination of lymphocytes. ${ }^{30}$ Lymphopenia in patients with COVID-19, was more evident in severe cases. ${ }^{12}$ Fan et al. ${ }^{15}$ had found prominent lymphopenia in the ICU patients as compared to the non-ICU patients and there was an increase in white blood cell count (WBC) and absolute lymphocyte count (ALC) as their clinical condition improved. Platelets are important immune cells in the human body, which play an important role in hemostasis, coagulation, vascular integrity maintenance, and inflammatory response. Significant thrombocytopenia has been reported in COVID-19 patients with multifactorial mechanisms responsible for it. ${ }^{10,11,15,17,21,22}$ The coronavirus can directly invade hematopoietic cells or bone marrow stromal cells, leading to hematopoietic inhibition. ${ }^{31}$ Extensive alveolar damage occurs in patients with COVID-19 and SARS. The lung tissue and pulmonary endothelial cells damage induced by a viral infection and high flow of oxygen can lead to activation, aggregation, and retention of platelets in the lung, and thus the formation of thrombus, which leads to the depletion of platelets. ${ }^{32,33}$ Infection with novel coronavirus causes cytokine storms in body fluids, aggravating the inflammatory response and thus stimulating the release of platelets. ${ }^{34,35}$ Among critically ill COVID-19 patients, thrombocytopenia is associated with a poor prognosis. ${ }^{16,17}$ Few studies have reported the rate of thrombocytopenia and highlighted an overall fivefold enhanced risk of severe COVID-19 in patients with a lower platelet count than the reference range. ${ }^{10-12,14,21}$ Platelets with high mean platelet volume (MPV) have been observed in hyper destructive thrombocytopenia cases. ${ }^{36}$ These large/ giant platelets observed in the circulation are young and metabolically active, which are released by the bone marrow as compensation for losses.

Clinical symptoms of COVID-19 include fever, cough, weakness, muscle pain, diarrhoea, and pneumonia that may cause a syndrome of acute respiratory distress, metabolic acidosis, septic shock, coagulation dysfunction, and organ failure such as liver, kidney, and heart failure. ${ }^{11,12,22}$ Routine examinations include complete blood count, coagulation profile, and serum biochemical test (including renal and liver function, creatine kinase, lactate dehydrogenase, and electrolytes). A complete blood count is the most available, efficient, and cost-effective laboratory investigation. The pulmonary manifestations of COVID-19 infection are predominantly characterized by ground-glass opacification with occasional consolidation on Computerised Tomography. ${ }^{37}$ In this report, we summarize the various hematologic parameters in COVID-19 positive patients in this study.

\section{MATERIALS AND METHODS}

Fifty patients with confirmed COVID-19 admitted to G.K. General Hospital \& Gujarat Adani Institute of Medical Sciences, Bhuj from 1st April 2020 to 30th June 2020 were enrolled in this study. A confirmed case of Covid-19 was defined by a positive result on a reverse-transcriptasepolymerase-chain-reaction (RT-PCR) assay of a specimen collected on a nasopharyngeal swab. ${ }^{38}$ The information recorded includes demographic features and hematological parameters through the hospital data management system. The samples of blood were collected at the time of admission, in the EDTA anticoagulant vacutainer. The samples were processed in Sysmex XN-1000 seven-part hematology analyzer. Hemoglobin (HB), Hematocrit (HCT), Red blood cell count (RBC), Mean corpuscular volume (MCV), Mean corpuscular hemoglobin $(\mathrm{MCH})$, Mean corpuscular hemoglobin concentration (MCHC), Red cell distribution width (RDW), WBC, Neutrophils (absolute 


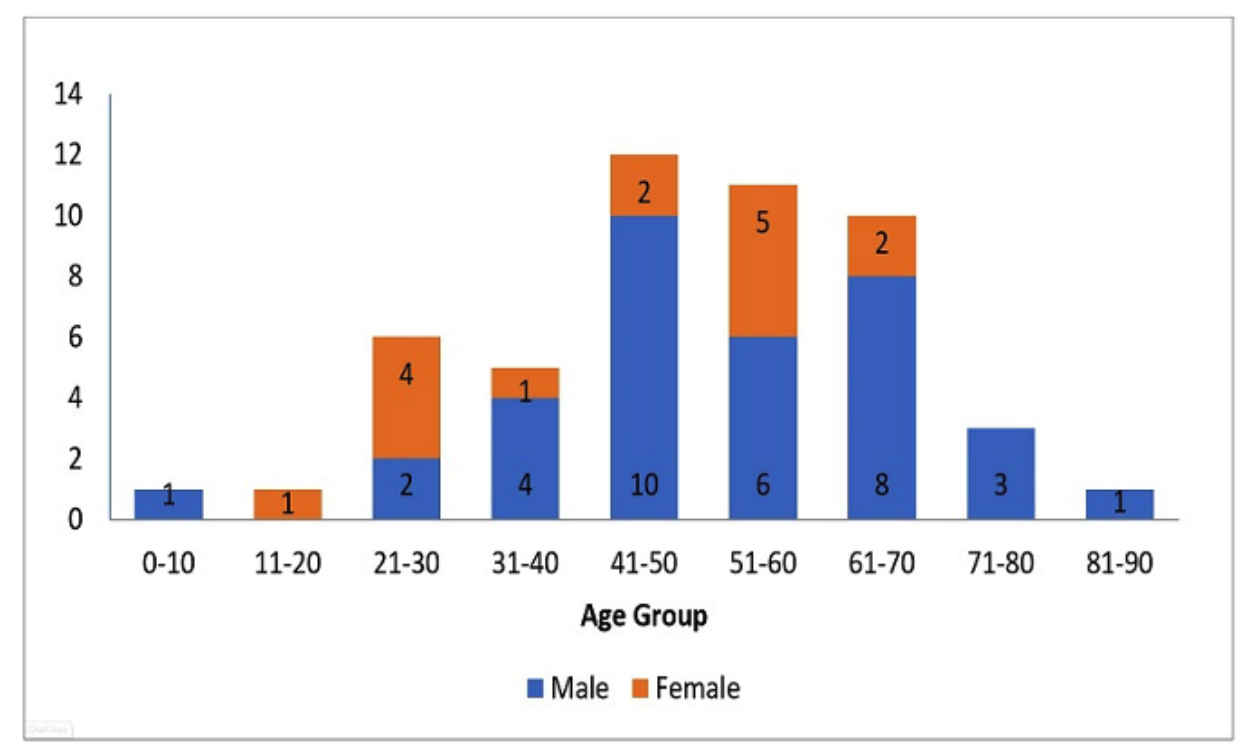

Figure 1: Histogram showing the age-wise distribution of COVID-19 positive patients. $(n=50)$

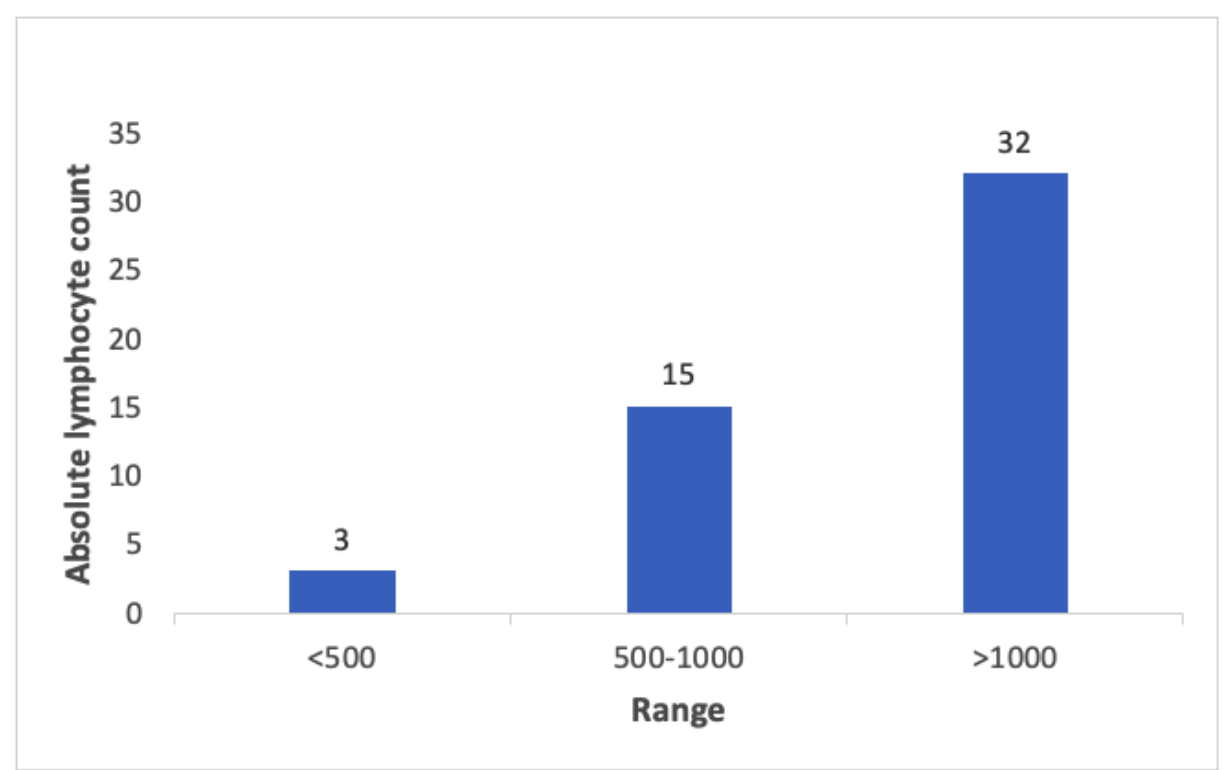

Figure 2: Histogram showing the distribution of lymphopenia among COVID-19 positive patients. $(N=50)$

count), Lymphocytes (absolute count), Platelet count and MPV were noted and are presented as a range, mean, median and standard deviation.

Diagnostic criteria for leukopenia:11 WBC $<4 \times 10^{9} / \mathrm{L}$, for lymphopenia; moderate lymphopenia (absolute lymphocyte count [ALC] 0.5-1 × 10\% $/ \mathrm{L}$ ), and severe lymphopenia (ALC $\left.<0.5 \times 10^{9} / \mathrm{L}\right)$.

Diagnostic criteria for thrombocytopenia:15 Mild thrombocytopenia (platelet count 100-150 $\times 10^{9} / \mathrm{L}$ ) and moderate thrombocytopenia (platelet count 50-100 $\times 10^{9} / \mathrm{L}$ ).

Descriptive statistics were used to summarize the data; results are reported as ranges or/and median as appropriate. Categorical variables were summarized as counts and percentages.

\section{RESULTS}

The study population comprised of 50 patients which comprised of 35 males $(70 \%)$ and 15 females (30\%) with an age range from 6 months to 82 years and twenty-five patients being above 50 years. Eleven cases were between 51-60 years and 10 cases between 61-70 years of age group and four cases above 71 years. (fig. 1)

HB ranged from 8.2-15.5 gm\%, with a median of 11.85 gm $\%$ (Mean $11.60 \mathrm{gm} \%$, S.D. $1.1 \mathrm{gm} \%$ ). HB was decreased 


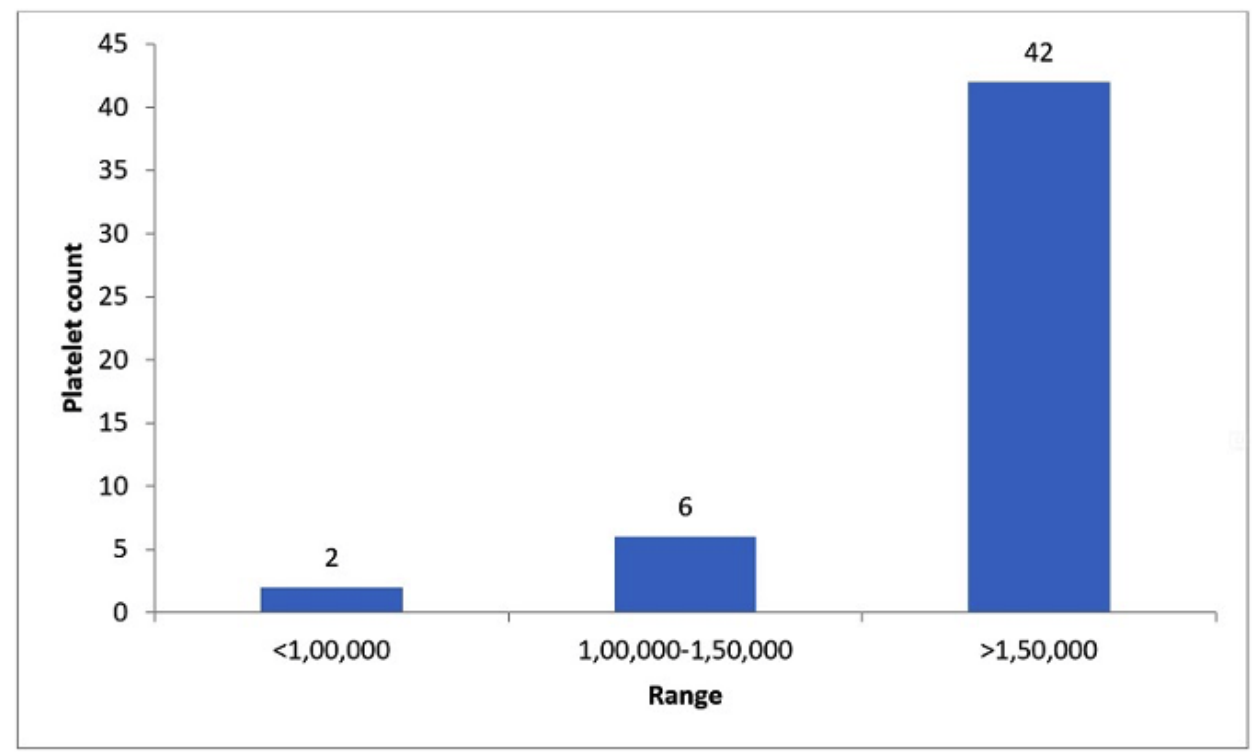

Figure 3: Histogram showing the distribution of thrombocytopenia among COVID-19 positive patients. $(n=50)$

in 18 cases (36\%) according to age and gender. HCT ranged from $24.8-52 \%$, with median of $37.1 \%$ (Mean $36.81 \%$, S.D. $6.97 \%$ ). HCT was decreased in 23 cases (46\%), values ranging from 10.4-35.8\%. Two cases showed raised HCT of 50.4 and $52 \%$. The rest of the cases had normal HCT ranging from 36.5-46.5\%. RBC Count ranged from 2.5 to 6.87 million, with a median of 4.72 million (Mean 4.66 million, S.D. 0.78 million). Fourteen cases ( $28 \%$ ) had reduced RBC mass ranging from 2.5-4.18 million, 34 cases (68\%) had normal RBC mass while 2 cases (4\%) had increased RBC mass as 6.45 and 6.87 million. MCV ranged from 54.7-110.8 $\mathrm{fl}$, with a median of $80.75 \mathrm{fl}$ (Mean 79.8\%, S.D. 9.8\%). In 7 cases (14\%) MCV was decreased ranging from 54.7-74.2 fl while 3 cases $(6 \%)$ had increased MCV ranging from 95.7-110.8 fl. The rest of the cases showed MCV within the normal range for the given age groups. $\mathrm{MCH}$ ranged from $16.9-38 \mathrm{pg}$ with a median of $28.1 \mathrm{pg}$ (Mean 27.8\%, S.D. $3.6 \%)$. In 16 case (32\%) MCH was decreased ranging from 16.9-27.4 pg and 2 cases (4\%) had increased MCH (33.5 \& $38 \mathrm{pg}$ ). MCHC ranged from 30.9-37.0 g/dl with median of $34.15 \mathrm{~g} / \mathrm{dl}$ (Mean $33.8 \%$, S.D. $1.5 \%$ ). In 15 cases $(30 \%)$ $\mathrm{MCHC}$ was decreased ranging from 30.9-33.2 $\mathrm{g} / \mathrm{dl}$ and 6 cases $(12 \%)$ had increased MCHC value ranging from 35.8 to $37 \mathrm{~g} / \mathrm{dl}$. RDW ranged from $11.5-19.7 \%$ with median of $13.05 \%$ (Mean $12.9 \%$, S.D. $0.8 \%$ ). Only 2 cases $(4 \%)$ had decreased RDW (11.5 \& 11.7\%) and 6 cases $(12 \%)$ had increase RDW ranging from 18.6 to $19.7 \%$. Overall there were no notable changes in $\mathrm{RBC}$ parameters apart from $\mathrm{HB}$ and HCT which could be due to pre-existing anemia.

Total WBC Count ranged from 3.4 to $23.21 \times 10^{9} / \mathrm{L}$, with a median of $7.3 \times 10^{9} / \mathrm{L}$. (Mean $8.7 \times 10^{9} / \mathrm{L}$, S.D. $4.6 \times 10^{9} / \mathrm{L}$ ). In 2 cases (4\%), leukopenia was noted with TLC of 3.4 \& $3.6 \times 10^{9} / \mathrm{L}$. Thirty-eight cases $(76 \%)$ had normal leucocyte count ranging from 4.03-10.35 x109/L including one infant with a TLC of $12.9 \times 10^{9} / \mathrm{L}$. Ten cases $(20 \%)$ had leucocytosis ranging from $12-23 \times 10^{9} / \mathrm{L}$. All these cases with high TLC showed neutrophilic predominance. The differential count in patients with leucopenia showed lymphocytic predominance in one case while neutrophilic predominance in the other case. The absolute neutrophil count ranged from $0.87-19.7 \times 10^{9} / \mathrm{L}$ with median of $6.8 \times 10^{9} / \mathrm{L}$ (Mean $5.4 \times 10^{9} /$ L, S.D. $\left.4.3 \times 10^{9} / \mathrm{L}\right)$. Only one case $(2 \%)$ showed moderate neutropenia $0.87 \times 10^{9} / \mathrm{L}$. Absolute lymphocyte count ranged from $0.37-3.28 \times 10^{9} / \mathrm{L}$. The median of absolute lymphocyte count was $1.12 \times 10^{9} / \mathrm{L}$ (Mean $1.2 \times 10^{9} / \mathrm{L}$, S.D. $\left.1.21 \times 10^{9} / \mathrm{L}\right)$. Absolute lymphopenia featured in eighteen patients (36\%) with fifteen patients (30\%) having moderate lymphopenia (range: $0.52-0.96 \times 10^{9} / \mathrm{L}$ ) and three patients $(6 \%)$ with severe lymphopenia (range: $\left.0.37-0.49 \times 10^{9}\right)$. (fig. 2)

The platelet count ranged from $90-540 \times 10^{9} / \mathrm{L}$. The median of platelet count was $249 \times 10^{9} / \mathrm{L}$ (Mean $272 \times 10^{9} / \mathrm{L}$, S.D. $\left.118 \times 10^{9} / \mathrm{L}\right)$. Six cases (12.0\%) had mild thrombocytopenia (range: $120-149 \times 10^{9} / \mathrm{L}$ ) and 2 patients (4\%) had moderate thrombocytopenia $\left(90 \times 10^{9} / \mathrm{L}\right.$ in both cases). Thirty-eight cases $(76 \%)$ had normal platelet count ranging from 153$449 \times 10^{9} /$ L. Four cases $(8 \%)$ had thrombocytosis (range: 497- $540 \times 10^{9} / \mathrm{L}$ ). (fig. 3) MPV ranged from 8.0-12.2, with median of $10.25 \%$ (Mean $10.31 \%$, S.D. $1.03 \%$ ). All 8 cases of thrombocytopenia showed high MPV ranging from 11.7$12.2 \%$ indicating the increased destruction of platelet and henceforth early release of young giant platelet. There was no significant difference in the CBC parameters mentioned above among the male and female populations.

\section{DISCUSSION}

In the presence of rapidly emerging novel coronavirus infection, identification of hematological parameters could help predict disease severity and prognosis thus guiding 
clinical care. Significant lymphopenia is becoming evident at this point.

There are eight retrospective studies from China by Guan $\mathrm{W}$ et $\mathrm{al}^{10}$, Huang et $\mathrm{al}^{11}$, Wang et $\mathrm{al}^{12}$, Wu et $\mathrm{al}^{13}$, Yang et $\mathrm{al}^{16}$, Zhou et $\mathrm{al}^{17}$, Liu et $\mathrm{al}^{21}$ and Chen et $\mathrm{al}^{22}$ comprising of $1099,41,138,201,52,191,12$ and 99 confirmed cases of COVID-19, respectively. The majority of patients in these studies were over 50 years of age with a median of around 55 years. The median age of patients in these studies was $47,49,56,59.7,56,54$ and 55.5 respectively. ${ }^{10-12,16,17,21,22}$ All these studies showed a male predominance $(58.1 \%, 72 \%$, $54.3 \%, 67 \%, 62 \%, 67 \%$ and $68 \%) .{ }^{10-12,16,17,21,22}$

Two studies from Singapore by Young et al. and Fan et al. included 18 (critically ill) and 69 (not critically ill) confirmed cases of COVID-19 respectively, ${ }^{14,15}$ with a median age of 47 and 41 years. One study showed a male predominance (55.2\%) while the other had equal sex distribution. ${ }^{14,15}$ Two studies from the USA by Arentz et al and Bhatraju et al were published including 21 and 24 critically ill confirmed cases of COVID-19. ${ }^{18,19}$ The median age was 58 and 51.9 years respectively. The age in these studies ranged from 22-95 years and 23-97 years. Both studies showed a male predominance $(82.1 \%$ and $70 \%){ }^{18,19}$ Two studies from India by Anurag A et al ${ }^{39}$ and Agrawal A et $\mathrm{al}^{40}$ comprised of 148 and 102 confirmed cases of COVID-19. The age in these studies ranged from 7-74 years (median 42.6 years) and 1085 years (median 32.5 years). Both studies showed a male predominance $(58.8 \%$ and $75.4 \%)$. In the present study majority of the case were above 50 years with a median age of 49 years and age range from 6 months to 82 years. Male predominance $(70 \%)$ was noted.

In the studies done by Guan et $\mathrm{al}^{10}$, Huang et $\mathrm{al}^{11}$, Young et $\mathrm{al}^{14}$, Fan et $\mathrm{al}^{15}$, Zhou et $\mathrm{al}^{17}$, Liu et $\mathrm{al}^{21}$ and Chen et $\mathrm{al}^{22}$ hemoglobin concentration (gm\%) were 13.4, 12.6, 13.5, $14.2,12.8,12.8 \mathrm{gm}$ and 14.8 respectively. In a study by Agrawal A et $\mathrm{al}^{40}$ hemoglobin concentration (gm\%) was $13.85 \& 13.12$ in asymptomatic and symptomatic patients respectively. In the present study $\mathrm{HB}$ concentration was 11.85 gm\% (range: $8.2-15.5$ ).

The median of total WBC count in a study by Huang et al. ${ }^{11}$ was $6.2 \times 10^{9} / \mathrm{L}, 4.5 \times 10^{9} / \mathrm{L}$ in Wang et al. ${ }^{12}, 5.94 \times 10^{9} / \mathrm{L}$ in Wu et al. ${ }^{13}, 4.6 \times 10^{9} / \mathrm{L}$ in Young et al. ${ }^{14}, 4.7 \times 10^{9} / \mathrm{L}$ in Fan et al. ${ }^{15}, 6.2 \times 10^{9} / \mathrm{L}$ in Zhou et al. ${ }^{17}$ and $8.4 \times 10^{9} / \mathrm{L}$ in Bhatraju et al. ${ }^{19}$ Chen et al. ${ }^{22}$ had 9 cases $(9 \%)$ with leukopenia and 24 cases $(24 \%)$ with leucocytosis. Two studies from India by Anurag A et al.$^{39}$ and Agrawal A et al. ${ }^{40}$ showed mean total WBC count $8.6 \times 10^{9} / \mathrm{L}$ and $7.1 \times 10^{9} / \mathrm{L}$ respectively. In the present study median of total $\mathrm{WBC}$ count was $7.3 \times 10^{9} / \mathrm{L}$ (3.4-23.2) and 2 cases (4\%) had leukopenia with TLC of 3.4 $\mathrm{x} 10^{9} / \mathrm{L} \& 3.6 \times 10^{9} / \mathrm{L}$.

The median of absolute neutrophil count in a study by Huang et al. ${ }^{11}$ was $5.0 \times 10^{9} / \mathrm{L}, 5.0 \times 10^{9} / \mathrm{L}$ in Wang et al. ${ }^{12}$,
$4.47 \times 10^{9} / \mathrm{L}$ in Wu et al. ${ }^{13}, 2.7 \times 10^{9} / \mathrm{L}$ in Young et al. ${ }^{14}$ and $2.6 \times 109 / \mathrm{L}$ in a study by Fan et al. ${ }^{15}$. Chen et al. ${ }^{22}$ found a median absolute neutrophil count of $5.0 \times 10^{9} / \mathrm{L}$ and 38 cases $(38 \%)$ had neutrophilia. In the present study, the absolute neutrophil count ranged from $0.87-19.72 \times 10^{9} / \mathrm{L}$ with a median of $6.8 \times 10^{9} / \mathrm{L}$. Only one case showed moderate neutropenia with a count of $0.87 \times 10^{9} / \mathrm{L}$.

In the study by Guan et a ${ }^{10}$ there were 914 patients out of 1099 with lymphopenia on admission while 370 cases (33.7\%) had leukopenia. Huang et al. ${ }^{11}$ highlighted an association between lymphopenia and the need for ICU care. They had 11 out of 13 cases $(85 \%)$ in ICU patients and 15 out of 28 cases $(54 \%)$ in Non-ICU patients with lymphopenia. Wang et al. ${ }^{12}$ had 97 out of 138 cases $(70.3 \%)$ with lymphopenia. $\mathrm{Wu}$ et al. ${ }^{13}$ showed an association between lymphopenia and the development of acute respiratory distress syndrome (ARDS). They had observed lymphopenia in 126 out of 201 cases $(64 \%)$. In a study by Young et al. ${ }^{14}$ lymphopenia was also documented in approximately $40 \%$ of the first 18 hospitalized patients with COVID-19 in Singapore. Fan et $\mathrm{al}^{15}$ reported lymphocytopenia in $24(36.9 \%)$ patients. In another retrospective study by Yang et al ${ }^{16}$ including 52 critically ill patients from Wuhan, China, lymphopenia was reported in 44 cases $(85 \%)$. Zhou et a ${ }^{17}$ published laboratory parameters in 191 COVID-19 cases, in which lymphopenia was noted in 77 cases (40\%), while 32 cases (17\%) had leukopenia. Studies by Arentz et $\mathrm{al}^{18}$ and Bhatraju et al ${ }^{19}$ in critically ill COVID-19 patients showed lymphopenia in 14 out of 21 cases (67\%) and 18 out of 24 cases $(75 \%)$ respectively. Tan et $\mathrm{al}^{20}$ in a study of COVID-19 patients (hospitalised and succumbed) by monitoring dynamic changes in blood showed that decreased lymphocyte percentage was associated with increased severity of the disease. Furthermore, they had demonstrated that lymphopenia can be used as a reliable indicator to classify the moderate, severe, and critically ill patient types by using the Time-lymphocyte $\%$ model for disease classification. Liu et $\mathrm{al}^{21}$ had 5 patients with lymphopenia in a study of 12 patients. In a study by Chen et $\mathrm{a}^{22}$ the median of absolute lymphocyte count was $0.9 \times 10^{9}$ with 35 cases (35\%) having lymphopenia. Agrawal $\mathrm{A}$ et $\mathrm{al}^{40}$ from India highlighted a comparison of hematological parameters among asymptomatic and symptomatic COVID-19 patients. They had 9 out of 17 cases (52.94\%) that were symptomatic and 10 out of 85 cases $(11.76 \%)$ of asymptomatic patients with lymphopenia. Total 19 out of $102(18.63 \%)$ patients with lymphopenia. In the present study lymphopenia (range: $\left.0.37-0.49 \times 10^{9} / \mathrm{L}\right)$ was found in 18 patients $(36 \%)$ with 15 (30\%) having moderate absolute lymphopenia and 3 patients $(6 \%)$ with severe absolute lymphopenia.

In the study by Guan et al ${ }^{10}$ median platelet count was 168 x109/L with 398 cases (36.2\%) had thrombocytopenia, $164.5 \times 109 / \mathrm{L}$ in Huang et al. ${ }^{11}$ with 2 cases $(4.9 \%)$ had thrombocytopenia, $163 \times 10^{9} / \mathrm{L}$ in Wang et $\mathrm{al}^{12}, 159 \times 10^{9} / \mathrm{L}$ in Young et $\mathrm{al}^{14}, 201 \times 10^{9} / \mathrm{L}$ in Fan et a ${ }^{15}$ with 13 patients 
(20\%) had mild thrombocytopenia, $206 \mathrm{x} 10^{9} / \mathrm{L}$ in Zhou et $\mathrm{al}^{17}$ with 13 cases $(7 \%)$ had thrombocytopenia, 160.3 $\mathrm{x} 109 / \mathrm{L}$ in Liu et $\mathrm{al}^{21}$ with 1 patient $(8.33 \%)$ had mild thrombocytopenia and $213.5 \times 10^{9} / \mathrm{L}$ in Chen et $\mathrm{al}^{22}$ with 12 patient (12\%) had thrombocytopenia. In the study by Agrawal A et $\mathrm{al}^{40}$ mean platelet count was $214 \times 10^{9} / \mathrm{L}$ in asymptomatic patients and $182 \times 10^{9} / \mathrm{L}$ in symptomatic patients. In the present study thrombocytopenia (range: 90 $\left.149 \times 10^{9} / \mathrm{L}\right)$ was found in 8 patients $(16 \%)$ with $6(12 \%)$ having moderate thrombocytopenia and 2 patients $(4 \%)$ with severe thrombocytopenia.

\section{Limitations of the study}

The data presented in this study are laboratory-based and have not been compared with the clinical status and radiological findings of the patients.

\section{CONCLUSIONS}

COVID-19 patients on admission showed marked lymphopenia, mild leukopenia, and thrombocytopenia. Other hematological parameters did not show any significant changes. Careful evaluation of laboratory indices at admission can be helpful to clinicians in formulating a treatment approach and promptly provide intensive care to those who are in greater need.

\section{Conflict of interest: None}

\section{REFERENCES}

1. Wang C, Horby PW, Hayden FG et al. A novel coronavirus outbreak of global health concern. Lancet (London, England). 2020;395:47073. $\underline{\text { Crossref }}$

2. Desforges M, Le Coupanec A, Dubeau P, et al. Human Coronaviruses and Other Respiratory Viruses: Underestimated Opportunistic Pathogens of the Central Nervous System?. Viruses. 2019;12:14. Crossref

3. Ksiazek TG, Erdman D, Goldsmith CS, et al. A novel coronavirus associated with severe acute respiratory syndrome. N Engl J Med. 2003;348:1953-66. $\underline{\text { Crossref }}$

4. Saad M, Omrani AS, Baig K, et al. Clinical aspects and outcomes of 70 patients with Middle East respiratory syndrome coronavirus infection: a single-center experience in Saudi Arabia. Int J Infect Dis. 2014; 29:301-6. Crossref

5. Walls AC, Park YJ, Tortorici MA et al. Structure, function, and antigenicity of the SARS-CoV-2 spike glycoprotein. Cell 2020. S0092-8674. Crossref

6. Doobay MF, Talman LS, Obr TD et al. Differential expression of neuronal ACE2 in transgenic mice with overexpression of the brain renin-angiotensin system. Am J Physiol Regul Integr Comp Physiol. 2007;292: R373-R381. Crossref

7. Zhu N, Zhang D, Wang W, et al. A Novel Coronavirus from Patients with Pneumonia in China, 2019. N Engl J Med 2020 Feb 20; 382: 727-33. Crossref

8. Terpos E, Ntanasis-Stathopoulos I, Elalamy I, et al. Hematological findings and complications of COVID-19. Am J Hematol. 2020;95:834-47. $\underline{\text { Crossref }}$

9. Zhang MQ, Wang XH, Chen YL, et al. Clinical features of 2019 novel coronavirus pneumonia in the early stage from a fever clinic in Beijing. Zhonghua Jie He He Hu Xi Za Zhi. 2020;43(0): E013. Crossref

10. Guan WJ, Ni ZY, Hu Y, et al. Clinical Characteristics of Coronavirus Disease 2019 in China. N Engl J Med 2020;382(18):1708-18. Crossref

11. Huang C, Wang Y, Li X et al. Clinical features of patients infected with 2019 novel coronavirus in Wuhan, China. Lancet 2020 Feb 15; 395(10223): 497-506. Crossref

12. Wang D, Hu B, Hu C, et al. Clinical Characteristics of 138 Hospitalized Patients With 2019 Novel Coronavirus-Infected Pneumonia in Wuhan, China. JAMA 2020;323(11):1061-1069. rossref

13. Wu C, Chen X, Cai Y, et al. Risk Factors Associated With Acute Respiratory Distress Syndrome and Death in Patients With Coronavirus Disease 2019 Pneumonia in Wuhan, China. JAMA Intern Med 2020;180(7):934-943. Crossref

14. Young BE, Ong SWX, Kalimuddin S, et al. Epidemiologic Features and Clinical Course of Patients Infected With SARS-CoV-2 in Singapore. JAMA 2020;323(15):1488-1494. Crossref

15. Fan BE, Chong VCL, Chan SSW, et al. Hematologic parameters in patients with COVID-19 infection. Am J Hematol. 2020;95(6): E131-E153. Crossref

16. Yang X, Yu Y, Xu J, et al. Clinical course and outcomes of critically ill patients with SARS-CoV-2 pneumonia in Wuhan, China: a singlecentered, retrospective, observational study. Lancet Respir Med. 2020; 8(5):475-81. $\underline{\text { Crossref }}$

17. Zhou F, Yu T, Du R, et al. Clinical course and risk factors for mortality of adult inpatients with COVID-19 in Wuhan, China: a retrospective cohort study. Lancet 2020; 395: 1054-62. $\underline{\text { Crossref }}$

18. Arentz M, Yim E, Klaff L, et al. Characteristics and Outcomes of 21 Critically Ill Patients With COVID-19 in Washington State. JAMA 2020;323:1612-14. Crossref

19. Bhatraju PK, Ghassemieh BJ, Nichols M, et al. Covid-19 in Critically Ill Patients in the Seattle Region - Case Series. N Engl J Med. 2020; 382:2012-22. $\underline{\text { Crossref }}$

20. Tan L, Wang Q, Zhang D, et al. Lymphopenia predicts disease severity of COVID-19: a descriptive and predictive study. Signal Transduct Target Ther. 2020; 5: 33. Crossref

21. Liu Y, Yang Y, Zhang $\mathrm{C}$, et al. Clinical and biochemical indexes from 2019-nCoV infected patients linked to viral loads and lung injury. Sci China Life Sci. 2020;63:364-74. Crossref

22. Chen N, Zhou M, Dong X, et al. Epidemiological and clinical characteristics of 99 cases of 2019 novel coronavirus pneumonia in Wuhan, China: a descriptive study. Lancet. 2020;395:507-513. Crossref

23. C. Mattiuzzi, G. Lippi, Which lessons shall we learn from the 2019 novel coronavirus outbreak? Ann. Transl. Med. 2020;8:48. Crossref

24. $\mathrm{Xu} \mathrm{H}$, Zhong L, Deng J, et al. High expression of ACE2 receptor of 2019-nCoV on the epithelial cells of oral mucosa. Int J Oral Sci 2020; 12: 8. Crossref

25. Singh S, Sharma A, Arora SK. High producer haplotype (CAG) of $-863 \mathrm{C} / \mathrm{A},-308 \mathrm{G} / \mathrm{A}$ and $-238 \mathrm{G} / \mathrm{A}$ polymorphisms in the promoter region of TNF-alpha gene associate with enhanced apoptosis of lymphocytes in HIV-1 subtype C infected individuals from North India. PLoS One 2014; 9(5): e98020. Crossref

26. Liao YC, Liang WG, Chen FW et al. IL-19 induces production of IL-6 and TNF-alpha and results in cell apoptosis through TNF-alpha. J Immunol 2002; 169(8): 4288-4297. Crossref

27. Aggarwal S, Gollapudi S, Gupta S. Increased TNF-alpha-induced apoptosis in lymphocytes from aged humans: changes in TNF-alpha receptor expression and activation of caspases. J Immunol 1999; 162: 2154-2161. Website

28. Chan JF, Zhang AJ, Yuan S, et al. Simulation of the clinical 
and pathological manifestations of Coronavirus Disease 2019 (COVID-19) in golden Syrian hamster model: implications for disease pathogenesis and transmissibility. Clin. Infect. Dis. 2020: ciaa325. Crossref

29. You B, Ravaud A, Canivet A, et al. The official French guidelines to protect patients with cancer against SARS-CoV-2 infection. Lancet Oncol 2020;21:619-621. Crossref

30. Fischer K, Hoffmann P, Voelkl S, et al. Inhibitory effect of tumor cell-derived lactic acid on human T cells. Blood 2007; 109: 3812 3819. Crossref

31. Eickmann M, Gravemann U, Handke W, et al. Inactivation of three emerging viruses severe acute respiratory syndrome coronavirus, Crimean-Congo haemorrhagic fever virus and Nipah virus - in platelet concentrates by ultraviolet $\mathrm{C}$ light and in plasma by methylene blue plus visible light. Vox Sang. 2020;115:146-51. Crossref

32. Pilaczyńska-Cemel M, Gołda R, Dabrowska A et al. Analysis of the level of selected parameters of inflammation, circulating immune complexes, and related indicators (neutrophil/lymphocyte, platelet/ lymphocyte, CRP/CIC) in patients with obstructive diseases. Cent Eur J Immunol. 2019;44:292-98. Crossref

33. Shinya K, Gao Y, Cilloniz C, et al. Integrated clinical, pathologic, virologic, and transcriptomic analysis of $\mathrm{H} 5 \mathrm{~N} 1$ influenza virus-induced viral pneumonia in the rhesus macaque. J Virol. 2012;86:6055-6066. Crossref

34. Ramana CV, DeBerge MP, Kumar A et al. Inflammatory impact of IFN- $\gamma$ in CD $8+T$ cell mediated lung injury is mediated by both Stat1dependent and-independent pathways. Am J Physiol Lung Cell Mol Physiol. 2015;308: L650-L657. Crossref
35. Liu Y, Gayle AA, Wilder-Smith A et al. The reproductive number of COVID-19 is higher compared to SARS coronavirus. J Travel Med. 2020;27: taaa021. Crossref

36. Numbenjapon T, Mahapo N, Pornvipavee R, et al. A prospective evaluation of normal mean platelet volume in discriminating hyperdestructive thrombocytopenia from hypoproductive thrombocytopenia. Int J Lab Hematol. 2008; 30:408 14. Crossref

37. Ng, M.-Y., Lee, E. Y., Yang, J., et al. Imaging Profile of the COVID-19 Infection: Radiologic Findings and Literature Review. Radiology: Cardiothoracic Imaging, 2020:2; e200034. Crossref

38. Corman VM, Landt O, Kaiser M, et al. Detection of 2019 novel coronavirus (2019-nCoV) by real-time RT-PCR. Euro Surveill. 2020;25:2000045. Crossref

39. Anurag A, Jha PK, Kumar A. Differential white blood cell count in the COVID-19: A cross-sectional study of 148 patients. Diabetes Metab Syndr. 2020; 14:2099-2102. Crossref

40. Agrawal A, Tyagi P, Mahavar S et al. Study of hematological and biochemical parameters in a cohort of Indian COVID-19 patients admitted in a tertiary care centre. Int J Adv Med 2020; 7:1840-5. Crossref 